\title{
Evaluation of haematological findings in 50 Bahraini patients with sickle cell disease and in some of their parents
}

\author{
M A BUHAZZA*, A B BIKHAZI $\dagger$, AND F P KHOURI \\ From the *College of Health Sciences, State of Bahrain; and the Department of Physiology and $\ddagger$ the \\ Department of Laboratory Medicine, American University of Beirut, Lebanon.
}

SUMmaRY The haematological findings in 50 Bahrainis with sickle cell disease are reported. This establishes the existence of the $\mathrm{Hb} \mathrm{S}$ gene in Bahrain. The mean $\mathrm{Hb} F$ level in the Bahraini patients was $13.8 \%$, a value lower than that encountered in sickle cell homozygotes from Kuwait and Saudi Arabia.

The clinical manifestations of sickle cell anaemia result from the presence of $\mathrm{Hb} \mathrm{S}$ in the erythrocytes of sickle cell patients. In addition to $\mathrm{Hb} S$ the erythrocytes of sickle cell patients may also contain variable amounts of fetal haemoglobin. ${ }^{1}$ Increased amounts of fetal haemoglobin apparently protect the erythrocytes from sickling, thereby reducing the secondary clinical manifestations. ${ }^{2}$ Saudi Arabs and other populations in the Middle East exhibit a benign type of sickle cell disease compared with Blacks in Africa and the Americas. ${ }^{3}$ This appears to result from the presence of relatively large amounts of fetal haemoglobin in their red blood cells. ${ }^{4}$ To our knowledge, no similar studies have been carried out on the Bahraini Arab population. The present investigation was undertaken to determine the existence of the sickle gene among Bahraini Arabs.

\section{Materials and methods}

\section{CONTROL SUBJECTS}

Cord blood from 21 Bahraini newborn infants and venous blood from 20 Bahraini clinically normal adults were collected and studied for the presence of abnormal haemoglobins. The procedure used for haemoglobin analysis was the microzone method for haemoglobin electrophoresis. ${ }^{56}$ Fetal haemoglobin values were determined by the alkali denaturation method of Singer et al. ${ }^{7}$ Quantitative estimation of haemoglobin $\mathbf{A}_{2}$ was obtained by column chromatography on diethyl amino ethyl cellulose (DEAE). ${ }^{8}$
The latter test was carried out only on blood from the adult group.

Fifty Bahraini subjects with sickle cell disease were initially identified with the haemoglobin solubility test followed by haemoglobin electrophoresis ${ }^{9}$ on cellulose acetate. Fetal haemoglobin was measured as for the control group. Other standard haematological tests were performed according to the procedures of Dacie and Lewis. ${ }^{9}$ The patients' age at the time of the study ranged from 11 months to 30 years. There were 22 females and 28 males.

FAMILY STUDY

Family study was possible in only 21 mothers and 16 fathers of 27 patients, as the rest refused the examination, and in one instance the father was dead.

\section{Results}

CONTROL SUBJECTS

The electrophoretic findings in the control group are summarised in table 1 . In all infants, the haemoglo-

TABLE 1 Data on control subjects.

\begin{tabular}{|c|c|c|c|c|}
\hline & $\begin{array}{l}\text { Electrophoretic } \\
\text { pattern }\end{array}$ & $\begin{array}{l}H b F A D \\
(\%)\end{array}$ & $\begin{array}{l}\mathrm{Hb} A_{2} \\
(\%)\end{array}$ & $\begin{array}{l}H b S \\
(\%)\end{array}$ \\
\hline Infants $(21)^{*}$ & $A+F$ & $\begin{array}{l}50-70 \\
(59 \cdot 4 \pm 1 \cdot 2)\end{array}$ & & \\
\hline Adults $(17)^{*}$ & A & $\begin{array}{l}0.8-3 \cdot 0 \\
(1 \cdot 48 \pm 0 \cdot 14)\end{array}$ & $\begin{array}{l}1 \cdot 7-3 \cdot 1 \\
(2 \cdot 04 \pm 0 \cdot 08)\end{array}$ & \\
\hline Adults $(3)^{*}$ & $A+S$ & $\begin{array}{l}1 \cdot 7-2 \cdot 0 \\
(1 \cdot 8 \pm 0.08)\end{array}$ & $\begin{array}{l}1 \cdot 3-2 \cdot 2 \\
(2 \cdot 04 \pm 0 \cdot 08)\end{array}$ & $\begin{array}{l}32-36 \\
(34 \cdot 3 \pm 1 \cdot 2)\end{array}$ \\
\hline
\end{tabular}

*Number in parentheses indicates the number of control subjects tested. 
bin pattern was AF. Seventeen out of 20 adult blood samples showed normal electrophoretic patterns. The remaining three subjects showed the AS pattern; their $\mathrm{Hb} \mathrm{F}$ and $\mathrm{Hb} \mathrm{A}_{2}$ values were within the normal range. The findings in these three adults are compatible with the sickle cell trait, so they were excluded from the study.

Table 2 shows the haematological data on the 50 patients with sickle cell disease. All showed two bands of haemoglobin on electrophoresis identified as $\mathrm{Hb} \mathrm{S}$ and $\mathrm{Hb} \mathrm{F} ; \mathrm{Hb} \mathrm{A}$ was absent. Seven patients had $\mathrm{Hb} F$ levels within the normal range, 17 had $\mathrm{Hb}$ $\mathrm{F}<10 \%$, and in the remaining 26 patients $\mathrm{Hb} \mathrm{F}$ was $>10 \%$. No statistically significant difference was found in the haematological findings between males and females within the different age groups of these patients

\section{FAMILY STUDY}

The results are summarised in table 3 . SA electrophoretic patterns were revealed in 16 mothers and 15 fathers. Two mothers and one father showed $\mathrm{SF}$ patterns and their $\mathrm{Hb} \mathrm{F}$ values were $18.3 \%$, $5.0 \%$, and $4.4 \%$, respectively. The last three mothers showed negative sickling tests and their electrophoretic pattern was normal. Most of the parents were consanguineous.

\section{Discussion}

The findings reported in this manuscript are the first on sickle cell disease from the State of Bahrain. A total of 50 cases was investigated. Family studies of both parents were possible in only 15 instances, and in another seven only one parent was available for

TABLE 2 Haematological data on 50 sickle cell disease patients.

\begin{tabular}{|c|c|c|c|}
\hline & Mean & Range & Remarks \\
\hline Hb G (\%) & $8 \cdot 9 \pm 0 \cdot 22$ & $5 \cdot 4-11 \cdot 5$ & Less than mean in 20 patients \\
\hline $\operatorname{PCV}(\%)$ & $26 \cdot 9 \pm 0 \cdot 7$ & $15-35$ & \\
\hline Platelet count $(\mu \mathrm{l})$ & $209000 \pm 13700$ & $92000-620000$ & Increased in 2 patients \\
\hline WBC $(\mu \mathrm{l})$ & $12200 \pm 1120$ & $4000-34400$ & More than $10000 \mu \mathrm{l}$ in 24 patients \\
\hline RBC $\left(10^{6} / \mathrm{mm}^{3}\right)$ & $(3.02 \pm 0.07) 10^{6}$ & $(2 \cdot 0-3 \cdot 9) 10^{6}$ & \\
\hline $\operatorname{MCV}(\mathrm{fl})$ & $88.4 \pm 0.9$ & $71-107$ & \\
\hline $\mathrm{MCH}(\mathrm{pg})$ & $29 \cdot 1 \pm 0 \cdot 3$ & $26-33$ & \\
\hline $\mathrm{MCH}(\%)$ & $33 \cdot 0 \pm 0 \cdot 3$ & $29-43$ & \\
\hline Reticulocyte (\%) & $5.7 \pm 0.79$ & $0 \cdot 3-20 \cdot 5$ & Raised in 12 patients \\
\hline HB F (\%) & $13 \cdot 8 \pm 1 \cdot 58$ & & \\
\hline
\end{tabular}

Electrophoretic pattern $\mathrm{S}+\mathrm{F}$ in all patients.

TABLE 3 Results of family studies.

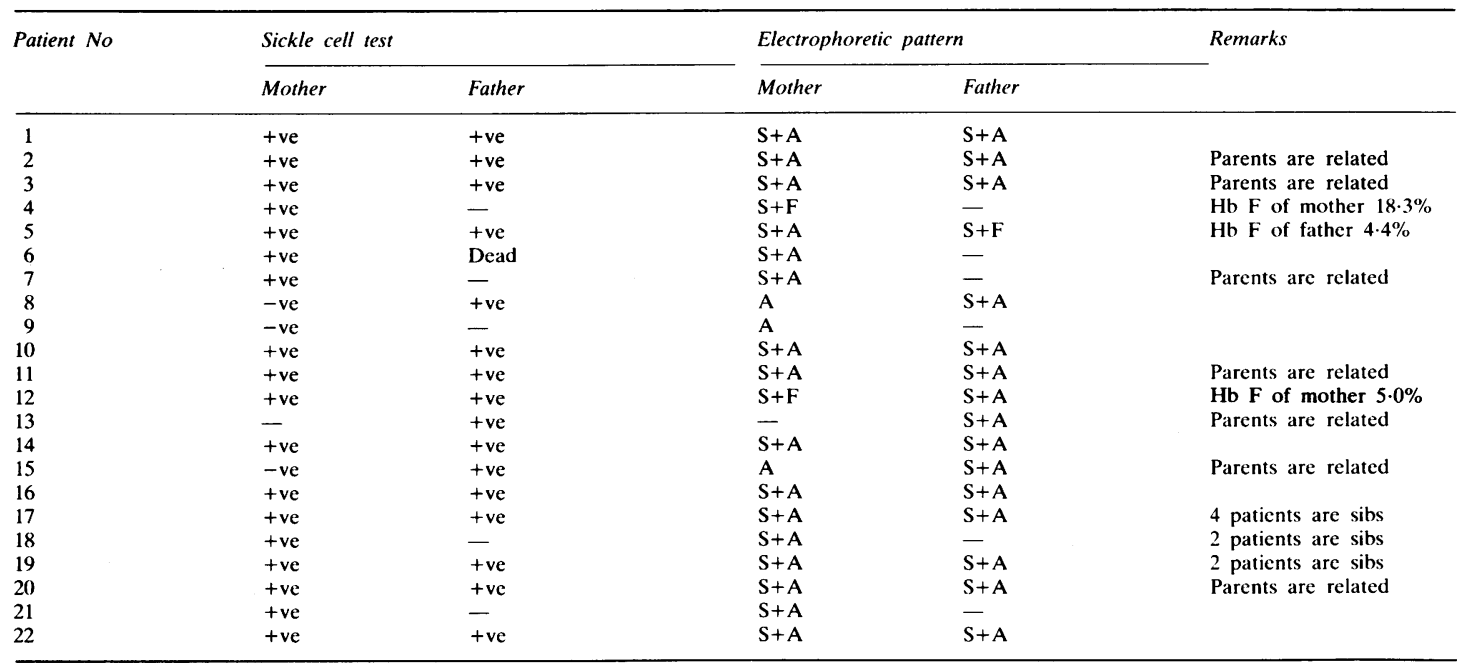


examination. Among the total number of parents examined, three out of 37 were themselves also homozygous for the disease and three mothers had no $\mathrm{Hb} \mathrm{S}$ and were presumably $\beta$ thalassaemia heterozygotes. The remaining 31 parents were $\mathrm{Hb} \mathrm{S}$ heterozygotes.

The results of this study also showed that $\mathrm{Hb} F$ levels ranged from normal to $54 \cdot 2 \%$, with a mean of about $14 \%$. This is lower than those encountered in Kuwait $^{10}$ and Saudi Arabia ${ }^{411} 12$ where the disease is relatively benign.

In conclusion, the above findings have established the existence of sickle cell disease in Bahrain. The presence of three heterozygotes for the $S$ gene in a control group of 20 adults suggests a high heterozygote frequency among Bahrainis. Further work with more adequate sampling is needed in order to determine the exact incidence of the sickle cell gene in this country.

The authors wish to acknowledge the Ministry of Health in the State of Bahrain for financial support. Thanks and appreciation are also extended to the management, staff, and students of the College of Health Sciences in Bahrain, and to $\mathrm{Dr} \mathrm{V}$ V Deshmakh and the staff and technicians of the Department of Pathology, Salmaniya Medical Centre, Bahrain for technical help.

\section{References}

1 Chernoff AI. Medical progress. Human haemoglobins in health and disease. $N$ Engl J Med 1955;253:365-74.
2 Jackson JF, Odom JL, Bell WN, Jackson M. Amelioration of sickle cell disease by persistent fetal hemoglobin. JAMA 1961:177:867-9.

${ }^{3}$ Gelpi AP. Benign sickle cell disease in Saudi Arabia: survival estimate and population dynamics. Clin Genet 1979;15:307-10.

4 Perrine RP, Weatherall DJ, May A. Benign sickle cell anaemia. Lancet 1972;ii:1163-7.

5 Bartlett RC. Rapid cellulose acetate electrophoresis. Clin Chem 1963;9:325-9.

${ }^{6}$ Graham JL, Grunbaum BW. A rapid method for microelectrophoresis and quantitation of hemoglobin on cellulose acetate. Am J Clin Pathol 1963;39:567-78.

${ }^{7}$ Singer K. Chernoff AI, Singer L. Studies on abnormal hemoglobins: their demonstration in sickle cell anemia and other hematologic disorders by means of alkali denaturation. Blood 1951;6:413-35.

${ }^{8}$ Huisman THJ, Dozy AM. Quantitative determination of the minor component $\mathrm{Hb} \mathrm{A}_{2}$ by DEAE cellulose chromatography. Ann Biol Chem 1961;2:400.

9 Dacie JV, Lewis SM. Practical haematology. 7th ed. Edinburgh, London, New York: Churchill Livingstone, 1975.

10 Ali SA. Milder variant of sickle cell disease in Arabs in Kuwait associated with unusually high level of fetal haemoglobin. $\mathrm{Br} J$ Haematol 1970:19:613-9.

${ }^{11}$ Perrine RP, Pembrey ME, John P, Perrine S, Shoup F. Natural history of sickle cell anaemia in Saudi Arabs: a study of 270 subjects. Ann Intern Med 1978;88:1-6.

12 Wood WG, Pembrey ME, Serjeant GR, Perrine RP, Weatherall DJ. Hb F synthesis in sickle cell anaemia: a comparison of Saudi Arab cases with those of African origin. $\mathrm{Br} J$ Haematol 1980;43:431-45.

Correspondence and requests for reprints to $\mathrm{Dr}$ Anwar B Bikhazi, Department of Physiology, American University of Beirut, Beirut, Lebanon. 